\title{
Adverse Reactions to Antiretrovirals in Cuban Patients Living with HIV/AIDS
}

\author{
Mayasil Morales-Pérez MD MS
}

\begin{abstract}
INTRODUCTION Disease and deaths from HIVIAIDS have decreased since antiretroviral treatment was introduced in 1996. Since 2005, as treatment availability has increased worldwide, deaths from HIVIAIDS have declined $48 \%$. As of November 2019, 26,952 cases have been reported in Cuba, of which $5159(19.1 \%)$ are deceased. The country has experienced a reduction in mortality rates since 2002, when antiretroviral treatment became available. Although there are clearly benefits to treatment, it is important to understand antiretroviral safety profiles as their toxicity may lower treatment adherence.
\end{abstract}

OBJECTIVE Describe adverse reactions attributable to antiretrovirals used in Cuban patients living with HIVIAIDS.

METHODS I studied notifications of adverse reactions to antiretrovirals used in Cuban patients with HIVIAIDS from January 2003 to December 2017. The sample consisted of 352 notifications in the National Pharmacovigilance Database regarding adverse reactions attributed to antiretrovirals. The variables considered were sex, notification year, antiretroviral drug, and number, type, frequency and severity of adverse reactions, whether or not they were preventable, and the reasons for categorizing them as they were.

\section{INTRODUCTION}

HIV is a major global health problem. By the end of 2019, 75.7 million people had contracted HIV since the beginning of the epidemic, and 32.7 million died of AIDS-related causes. In 2019, 1.7 million persons were infected with the virus, despite global campaigns to reduce transmission. The introduction of antiretroviral therapy has reduced deaths and contributed to the perception of HIVIAIDS as a chronic disease.[1]

Effective treatment to achieve maximum, prolonged plasma viral load suppression is based on early individualized use of a combination of antiretroviral drugs administered sequentially.[1] Therapy should include at least three antiretrovirals with at least two different mechanisms of action. Introduction of this treatment regime led to radical changes in the infection's natural history, although over time it became clear that the main limitation of antiretrovirals was their toxicity.[2] Because they are taken indefinitely, longterm toxicity increases, adherence decreases, and patients leave

\section{IMPORTANCE}

This study updates the safety profile of antiretrovirals used in Cuban patients living with HIVIAIDS, children of seropositive mothers, and those accidentally exposed to the virus. Profiles are important for improving treatment regimens by reconfiguring the therapeutic combinations recommended in international standards for specific patients. Safety profiles also provide information for personalized treatment.
RESULTS Antiretrovirals reported an average adverse reaction rate of 2.1 per million population per year, representing $24.2 \%$ of adverse reactions produced by the antiviral drug group in that period. Adult males represented $75 \%(264 / 352)$ of patients who had adverse reactions to antiretrovirals. Most adverse reactions were in response to nevirapine $(29.0 \% ; 102 / 352)$ and zidovudine $(26.7 \% ; 94 / 352)$. The most frequent reactions were hypersensitivity $(24.4 \%$; $86 / 352)$, digestive disorders (15.9\%; 56/352) and anemia (15.6\%; 55/352). Reactions were common $(62.5 \% ; 220 / 352)$ and moderate in severity (70.4\%; 248/352). Preventable reactions made up 52.6\% (185/352) of adverse reactions. Of preventable reactions, $68.1 \%$ (126/185) were associated with drug interactions and $16.2 \%$ (30/185) with improper dosage or prescription errors.

CONCLUSIONS Adverse reactions to antiretrovirals in Cuban patients are common and moderate in severity. The drug with the most notifications was nevirapine, and the most common adverse reaction was hypersensitivity. More than half of adverse reactions are considered preventable, and their main causes are prescription errors.

KEYWORDS Drug-related side effects and adverse reactions, antiretroviral agents, secondary prevention, tertiary prevention, Cuba

treatment, which fosters both the appearance and transmission of resistant strains.[3]

Timely detection of HIV infection allows early treatment, which reduces illness and death from AIDS. Starting antiretroviral treatment upon diagnosis reduces deaths,[4] gives infected persons a life expectancy similar to that of uninfected persons, and lowers transmission rates in couples with one uninfected person. One of the main obstacles to effective response to the HIVIAIDS epidemic is late diagnosis.[4,5]

From 2010 to 2019, new HIV infections worldwide decreased by $23 \%$ in adults and $52 \%$ in children. Antiretrovirals capable of reducing viral loads to zero played an essential role in this reduction, as did increased protective measures. Until June 2020, only 26 million infected people had access to antiretroviral therapy, or about $68 \%$ of HIV-positive individuals worldwide. Since their 2004 peak, deaths from the virus have dropped more than $60 \%$. However, many people in low- and middle-income nations cannot access antiretrovirals, although $\mathrm{WHO}$ and the UN have proposed 2030 as the year of zero AIDS-related deaths, zero new infections and zero discrimination against people living with HIVIAIDS.[5-8]

As of November 2019, 26,952 cases of HIV had been reported in Cuba. By the end of that year, prevalence was $0.4 \%$ in people aged 15-49 years, the lowest in the region, and one of the lowest in the world. AIDS was responsible for $89.9 \%$ of the 5159 deaths from HIV.[9]

Treatment with domestically-produced generic antiretrovirals began in mid-2001 as part of a national strategy to ensure full 
treatment access for HIVIAIDS patients. Cuban Therapeutic Guidelines were updated in 2002.[9] These advised that treatment should begin as soon as a person is diagnosed as seropositive, based on clinical, immunologic and virologic criteria established by the scientific community.[9] When Cuban generics were introduced, infection-related health indicators changed because of the clinical efficacy of antiretrovirals.[10] The number of deaths and opportunistic infections greatly decreased, survival increased, treatment became more accessible, and patient quality of life improved.[11] By 2003, the Cuban health system guaranteed access and free treatment to $100 \%$ of HIV-positive patients. Manufacturing generic drugs in-country that replaced imports increased therapeutic benefits and allowed potential savings of US\$46 million in the first decade that they were produced.[12,13]

The antiretrovirals currently used are divided into several subgroups: nucleoside reverse transcriptase inhibitors (NRTIs: stavudine, lamivudine, zidovudine, abacavir), non-nucleoside reverse transcriptase inhibitors (NNRTIs: nevirapine, efavirenz), protease inhibitors (indinavir, ritonavir, saquinavir), entry inhibitors (also called fusion inhibitors: enfuvirtide), integrase inhibitors (raltegravir, elvitegravir, dolutegravir), and coreceptor antagonists (maraviroc).

Most adverse reactions to these drugs are tolerable, although some may be serious and show drug group effects common to antiretrovirals with the same mechanism of action. Nucleoside reverse transcriptase inhibitors produce mitochondrial damage and protease inhibitors cause metabolic changes, while non-nucleoside reverse transcriptase inhibitors do not have these effects. Adverse reactions in nonnucleoside reverse transcriptase inhibitors are drug-specific and can range from variable-intensity hypersensitivity reactions to neurological disorders. Hypersensitivity is caused by an immune response to some element of the drug and can provoke reactions as varied as skin lesions, to Stevens-Johnson syndrome, epidermal necrolysis, eosinophilia and other systemic reactions. $[14,15]$ In general, treatment benefits outweigh the risk of adverse reactions. As understanding of drug safety profiles increases, treatment protocols improve, and as treatment options improve, patients are less likely to experience adverse reactions.[14,15]

Drug interactions are common because of the idiosyncrasy of these drugs (many are enzyme inductors or inhibitors), and other drugs prescribed to patients. Several studies describe clinically significant drug interactions that could cause adverse reactions in $20 \%-30 \%$ of patients. We do know that protease inhibitors and non-nucleoside reverse transcriptase inhibitors are the antiretroviral subgroups with the most potential interactions.[1,9]

Cuba's antiretroviral pharmacovigilance program offers a model of active drug surveillance. Latin America and Caribbean nations are making efforts to document these adverse reactions. In Mexico, this documentation is relatively new, with most issues reported reflecting notification quality and patients abandoning treatment due to adverse reactions, leading to an assumption of under-reporting. Although Cuba has an established, globally recognized pharmacovigilance program, under-reporting still exists because of various factors influencing notifications and their quality.[16] According to annual pharmacovigilance reports in Cuba, adverse drug reactions (ADRs) to antiretrovirals represent $0.09 \%$ of total notifications about antimicrobials.[17] Among all ADR reports, antimicrobials as a drug group are responsible for the most reports.[18]
Cuban studies on this topic have been limited to one institution or region of the country, and have not considered whether the ADRs were preventable.[19-21] One previous study examined this problem, but included all groups of antivirals, not specifically antiretrovirals.[17] The goal of this study is to describe adverse reactions to antiretrovirals reported in Cuba from 2003 to 2017.

\section{METHODS}

Study type A pharmacovigilance study was performed using a case series design. The sample consisted of 352 antiretroviral-drug ADR notifications entered into the National Pharmacovigilance Database (FarmaVigiC) of the National Pharmacovigilance Coordinating Unit (UCNFv)[22] from January 2003 to December 2017.

\section{Study variables The variables were:}

- Adverse reaction identified as the main adverse effect, specifying the condition of the patient. We used Uppsala Monitoring Centre adverse reaction terminology.[23]

- Notification year

- Age of children (0-17 years), adults (18-59 years) and persons aged $\geq 60$ years.[22]

- Sex

- Antiretroviral drug

- Frequency: common, uncommon, rare, undescribed. Classified according to the criteria of the Cuban Pharmacovigilance System,[22] which uses the categories and events within each category established for each drug in the National Drug Formulary. The total number of occasional, rare and undescribed adverse reactions were coded together as low-frequency adverse reactions.

- Severity: mild, moderate, severe and fatal. Minor reactions that did not require an antidote, treatment or hospitalization, with easily tolerated symptoms or signs, were classified as mild. Reactions were considered moderate if they required a change in drug treatment or increased observation and caused malaise that interfered with regular activities. They were considered severe when they were life-threatening or caused disability. They were considered fatal when they contributed directly or indirectly to the cause of death.

- Preventable adverse reaction: yes or no, depending on the answer from the Schumock and Thornton preventability algorithm, modified by Otero.[24,25]

- Preventable ADR causes: A cause was considered preventable when there were improper drug instructions, dose, route of administration, intervals of administration or treatment length, a history of adverse effects or allergic reactions to the drug, a drug interaction, or self-medication.

Causality was not among the variables assessed. It was used only as an inclusion criterion for the filters to select the study sample and establish whether ADRs were preventable.

Data collection The information was obtained from FarmaVigiC, which receives spontaneous ADR reports. The database stores information contained in the official template from suspected adverse reaction reports electronically submitted to UCNFv from different levels of the national health system. Reports are made by physicians, nurses and pharmacists caring for patients who take these medications and experience ADRs.

The database was filtered for the field "drug class," and the term "antiretroviral" and the "suspected drug" was used as the inclu- 
sion criterion, which included all drugs classified as antiretrovirals in the Cuban National Drug Formulary and international literature. The database was also filtered for "causality," where the categories "definite," "possible" or "probable" were used because they indicate a positive cause-effect relationship between the drug and the ADR. This was done to determine if the ADR was preventable, and was used only as a filter to define the sample. An Excel database was created with the results and named "primary database." This database stored the remaining fields in FarmaVigiC. The study universe comprised adverse reactions contained in the primary database.

After selecting the ADRs contained in the primary database, the Schumock and Thornton algorithm,[24] modified by Otero,[25] was used to identify preventable ADRs. A "yes" answer to the preventability question indicated that the ADR could have been prevented. Using these databases, a new database was created ("secondary database"), which stored all FarmaVigiC fields. An expert from the UCNFv created both databases without changing variable classifications or assessments.

Potentially preventable reactions were determined based on the information contained in FarmaVigiC, which is validated and verified by trained pharmacovigilance experts. Quality of FarmaVigiC notifications is ensured by regular data review and standardization using different levels of filters according to the quality standards of the Uppsala Monitoring Centre (UMC), the governing body of the WHO Programme for International Drug Monitoring.[22,23] Professionals in Cuban municipalities and provinces receive annual pharmacovigilance training and are supervised by UCNFv specialists.[22]

Data analysis Absolute and relative frequencies and reporting rates of ADRs for antiretrovirals were estimated per year and per million population, by sex and using the population data reported by the National Health Statistics Yearbook.[26] Proportions of patients treated with each antiretroviral were not calculated because the data were not available. The frequency distribution for each drug was estimated based on the total number of notifications.

Ethics The Cuban Ministry of Public Health's National Drug Division authorized the use of information in FarmaVigiC. Privacy was respected, and no patients who reported antiretroviral ADRs were identified.

\section{RESULTS}

During 2003-2017, the new, primary database (filtered FarmaVigiC data) included 352 antiretroviral ADRs. This figure is equivalent to an average reporting rate of 2.09 per million population annually, representing $24.2 \%$ of all adverse reactions produced by the antiviral drug class during this period.

Most ADRs were reported from 2009 to 2016, with the greatest share in the final year (85/352; 24.1\%). From 2003 to 2005 and in 2007, no antiretroviral ADRs were reported.

Male patients accounted for $77.3 \%(272 / 352)$ and female patients for $22.7 \%$ (80/352) of total ADRs notified in the study period. ADR notifications were more common in adults, with higher proportions in men $(272 / 352 ; 77.3 \%)$ than in women $(80 / 352 ; 22.7 \%)$. A single report in children was made, and there were no reports in persons aged $>60$ years.
Of the antiretrovirals, nevirapine had the highest number of reports, followed by zidovudine (Table 1).

Formulations containing combinations of antiretrovirals from different groups at fixed doses (Kaletra, Atripla, Truvada, etc.) were responsible for $4.3 \%(15 / 352)$ of reports.

Hypersensitivity reactions accounted for the greatest number of ADRs, followed by digestive disorders and anemia, in which the number of reports differed by a single report. Although hepatotoxicity is not one of the most common ADRs $(8.2 \% ; 29 / 352)$, it needs to be considered because of its severity (Table 2 ).

There were 9.1\% (32/352) of ADR notifications grouped as "other reactions" because of their infrequent occurrence. Among these were psychiatric and sleep abnormalities and metabolic, hematologic and vascular disorders, as well as headache and conditions caused by hydroelectrolyte imbalances.

Antiretroviral ADRs were common (62.5\%; 220/352). The most common were those of moderate severity (Table 3). Some ADRs, $5.4 \%$ (19/352), are not described in the Cuban National Drug Formulary. Any ADRs recorded in the system that do not appear in the National Formulary are reported to the pharmaceutical industry to be evaluated for inclusion in the formulary, depending on their frequency and importance.

No fatal ADRs were reported.

Preventable ADRs made up 52.5\% (185/352) of all notifications. Main causes were drug interactions (with drugs in the same drug class or any other that the patient was taking), inappropriate dosage, and a history of ADRs to the suspected drug. Drug interactions alone made up nearly $70 \%$ of preventable reactions (Table 4 ).

\section{DISCUSSION}

In Cuba, HIV infection is more common in men than women, in a ratio of $4: 1$. Men are therefore the largest group of antiretroviral consumers in the country, which would explain the higher percentage of ADRs in males.[9] These results were similar to those obtained in Paraguay, where $62.2 \%$ of antiretroviral ADRs were reported in men.[27] A study conducted in Cuba showed that ADRs were more common in adult males.[28]

Table 1: Adverse reactions to antiretrovirals, by medication

\begin{tabular}{|l|r|}
\hline Antiretroviral & \multicolumn{1}{|c|}{ Total (\%) } \\
\hline Nevirapine & $102(29.0)$ \\
\hline Zidovudine & $94(26.7)$ \\
\hline Stavudine & $46(13.1)$ \\
\hline Efavirenz & $29(8.2)$ \\
\hline Lamivudine & $19(5.4)$ \\
\hline Indinavir & $18(5.1)$ \\
\hline Fixed-dose combinations & $15(4.3)$ \\
\hline Ritonavir & $8(2.3)$ \\
\hline Abacavir & $7(2.0)$ \\
\hline Atazanavir & $6(1.7)$ \\
\hline Tenofovir & $5(1.4)$ \\
\hline Saquinavir & $3(0.9)$ \\
\hline Total & $352(100.0)$ \\
\hline Source: FarmaVigic database &
\end{tabular}

Source: FarmaVigiC database 
Table 2: Adverse reactions to antiretrovirals, by type

\begin{tabular}{|r|r|}
\hline Reaction type & \multicolumn{1}{|c|}{ Total (\%) } \\
\hline Hypersensitivity reactions & $86(24.4)$ \\
\hline Digestive disorders & $56(15.9)$ \\
\hline Anemia & $55(15.6)$ \\
\hline Polyneuritis & $42(11.9)$ \\
\hline Other reactions* & $32(9.1)$ \\
\hline Lipodystrophy & $30(8.5)$ \\
\hline Hepatotoxicity & $29(8.2)$ \\
\hline Stevens-Johnson syndrome & $9(2.6)$ \\
\hline Renal lithiasis & $6(1.7)$ \\
\hline Nephrotoxicity & $4(1.1)$ \\
\hline Fever & $3(0.9)$ \\
\hline Total & $352(100.0)$
\end{tabular}

*psychiatric and sleep abnormalities; metabolic, hematologic and vascular disorders; headache and conditions caused by hydroelectrolyte imbalances Source: FarmaVigiC database

Table 3: Adverse reactions to antiretrovirals, by severity and frequency

\begin{tabular}{|c|c|c|c|c|}
\hline \multirow{2}{*}{ Frequency } & \multicolumn{3}{|c|}{ Severity } & \multirow[b]{2}{*}{ Total $(\% *)$} \\
\hline & Mild & Moderate & Severe & \\
\hline Common & $47(13.4)$ & $163(46.3)$ & $10(2.8)$ & $220(62.5)$ \\
\hline Uncommon & $14(4.0)$ & $52(14.8)$ & $5(1.4)$ & $71(20.2)$ \\
\hline Rare & $12(3.4)$ & $20(5.7)$ & $10(2.8)$ & $42(11.9)$ \\
\hline Undescribed & $3(0.9)$ & $13(3.7)$ & $3(0.9)$ & $19(5.5)$ \\
\hline Total (\%) & 76 (21.6) & $248(70.5)$ & $28(8.0)$ & $352(100.0)$ \\
\hline
\end{tabular}

${ }^{*}$ All percentages were calculated using the grand total $(n=352)$

Source: FarmaVigiC database

Table 4: Adverse reactions to antiretrovirals, by preventable cause

\begin{tabular}{l|r}
\hline Causes & \multicolumn{1}{|c|}{ Total (\%) } \\
\hline Drug interaction & $126(68.1)$ \\
\hline Improper dose & $30(16.2)$ \\
\hline History of adverse reactions & $28(15.1)$ \\
\hline Improper length of treatment & $1(0.5)$ \\
\hline Total & $185(100.0)$
\end{tabular}

Source: FarmaVigiC database

Antiretroviral nevirapine had the highest proportion of ADRs. According to the literature, this drug is well-tolerated long term, although during treatment initiation, $15 \%-20 \%$ of patients may experience allergic reactions.[12] This could explain some of the ADRs attributed to nevirapine despite its reported good tolerance. According to reports on Cuban treatment protocols, in 2006, $66 \%$ of patients followed a regimen that included nevirapine.[11] Recent studies show sex-dependent variations in biotransformation of this drug that induce reactive metabolite formation in women,[29-32] so toxicity should be greater in female patients. However, available information does not specify sex distribution of the ADRs for nevirapine. Treatment regimens have now changed, and nevirapine is used only as an alternative drug in second-line treatment, due to ADR frequency.[12]

In a 2011-2013 study in Cuba, nevirapine had the most ADR notifications,[19] but in another study conducted at the same site in 2015 , its notifications ranked third. At that time, zidovudine and efavirenz had higher adverse reaction frequencies, but the authors did not explain the possible causes.[20] Data from that study show that in Cuba, antiretroviral-related ADRs are mainly associ- ated with nucleoside reverse transcriptase inhibitors (NRTIs) or non-nucleoside reverse transcriptase inhibitors (NNRTIs), which are the subgroups most often used in combination treatment regimens.

According to a study by Bastida,[32] polymedication due to the combined use of NNRTI antiretrovirals with medications for comorbidities is four times more common than in the general population because non-communicable chronic diseases appear sooner in patients living with HIV. This increases the risk of interactions and toxicity. The benefits from synergy among the active ingredients of antiretrovirals justify their combined use, and although ADRs are reported, interactions are more common with protease inhibitors, so NRTIs and NNRTIs are considered a safer alternative.

All antiretrovirals can cause hypersensitivity reactions, but NNRTIs are the ones most often linked to ADRs. Nevirapine is a common cause, as is, to a lesser extent, efavirenz. Most patients who develop a skin rash with nevirapine do so with efavirenz, but if the reverse occurs and the rash is caused by efavirenz, use of nevirapine is not recommended.[33] This should be made clear in patient treatment protocols.

Digestive disorders were the second-most common ADR, followed by anemia, lipodystrophy and hepatotoxicity, findings similar to those of other studies conducted in Cuba, although not always in this order of frequency.[19,20,28] In other nations such as Ecuador, the most common adverse effects are gastrointestinal disorders, and lipodystrophy is the most common chronic effect following antiretroviral therapy. Lipodystrophy is a pathological change in adipose tissue distribution, associated with metabolic complications from the effect of antiretrovirals on adipocytes. It is a characteristic reaction to drugs such as stavudine, lamivudine, zidovudine and emtricitabine, among others, which are in the NRTI subgroup and still among the drugs used in first-line treatment.[29] Because of their conditions and comorbidities, persons living with HIV are polymedicated. This may increase toxicity from interactions among antiretrovirals or with other drugs to treat associated pathologies, thus increasing the number of ADR reports.[34]

No ADRs were reported in persons aged $>60$ years, understandable since in Cuba ADRs are concentrated in those aged 40-49, 25-29, and 20-24 years. Chronicity and increased survival lead to a higher average age of infected persons, but HIV incidence in older adults is low, which explains why interactions with drugs for comorbidities occurring in these age groups are uncommon. Interactions described in this study as the cause of ADRs occur more commonly with other antiretrovirals than with antiretrovirals and other drugs.[11]

New treatment strategies with fixed-dose combinations of antiretrovirals are based on the premise that combining these drugs simplifies treatment and improves adherence and compliance. These combinations also improve quality of life and decrease the risk of medication errors and drug resistance.[35]

By and large, preventable ADR causes were prescription errors. Prescription errors were related to the fact that antiretrovirals were administered in fixed-dose combinations and all patients did not tolerate them equally. This is important because treat- 
ment is based on positive synergy of two or more antiretrovirals and is governed by established protocols.[12,38] These results could be useful for helping health system decisionmakers find safer treatment options to prevent this type of error. It is important for patients to receive proper doses of the different antiretrovirals used in combination therapy. The interactions among these drugs can lead to better results because a stronger effect can be obtained with lower doses. Nevertheless, individual differences and genetic polymorphisms in $\mathrm{ABC}$ superfamily membrane transporters contribute to resistance and predispose patients to toxicity.[12]

Nine clinical trials conducted in the United States and Europe during 2000-2013 discovered increased transmission of mutations linked to antiretroviral resistance. For NNRTIs specifically, this resistance increased from $0.3 \%$ to $2.7 \%$, because this drug subgroup is inexpensive and frequently used, especially in lowincome countries.[30,36] The emergence of resistance from prolonged exposure is one of the current challenges in the global response to the HIVIAIDS pandemic. ABC superfamily transporters are essential proteins for drug absorption and elimination in the body, and polymorphisms in the genes that code these proteins may cause a loss of response to certain drugs, even at therapeutic concentrations.[37] Genetic polymorphisms found in the ABCB1 subfamily are involved in cellular resistance to the protease inhibitor drug subclass (indinavir, ritonavir, adefovir). The overexpression of multidrug resistance protein 4 (Mrp4) is associated with drug resistance to nucleoside reverse transcriptase inhibitors.[37]

HIV's mutation potential generates variants that bind to the viral genome and are transmitted to new virions that emerge from virusreplicating infected cells and create new viral populations resistant to one or more antiretroviral drugs. In 2019, WHO reported increased prevalence of simultaneous resistance to several anti- retroviral groups, which means that possible changes to established, validated treatment protocols need to be assessed.[38] This phenomenon, known as triple resistance, increased more than $10 \%$ in low- and middle-income countries.[39-40] In mid2020 the world's first case of pandrug resistance was reported in a patient infected with HIV-1 subtype B, who showed resistance to five oral antiretroviral groups.[41]

Among the limitations of working with FarmaVigiC is that it does not allow evaluation of treatment adherence, which is negatively related to toxicity. Toxicity influences treatment adherence because the more adverse reactions or signs of toxicity patients experience, the less likely they are to adhere to treatment regimens. ADR reports sent to the database are based on spontaneous patient declarations, which favors under-reporting and does not distinguish between noncumulative and cumulative effects. The latter occur when a certain threshold is reached, beyond which the drug can produce ADRs. The spontaneous notification system does not allow ADR frequency to be determined in the total number of patients who took the drugs, because the exact number of persons using them is unknown. In this case, these are not only patients living with HIVIAIDS, but also infants born to seropositive mothers and those who had accidental contact with the virus (medical and paramedical staff, and researchers). Despite these limitations, this record system is the most complete and reliable source of data available for information about pharmacovigilance in Cuba.

\section{CONCLUSIONS}

In Cuba, ADR reports for antiretrovirals are rare, classified as frequent and of moderate severity, and are mainly hypersensitivity reactions. The antiretrovirals that most often cause them are nevirapine and zidovudine. Most ADRs occur in adult males, and more than half are considered preventable. The most common causes of preventable ADRs are prescription errors. 1 .

\section{REFERENCES}

1. Soto Ramírez LE. Guía de manejo antirretroviral de las personas con $\mathrm{VIH}$. 5th ed [Internet]. Mexico City: Conasida; 2012 [cited 2018 Apr 1]. 5 p. Available at: www.salud.gob.mx/conasida. Spanish.

2. HIVinfo.NIH.gov [Internet]. Washington, D.C.: U.S Department of Health and Human Services; c2021. Tratamiento del VIH. Tratamiento del VIH: conceptos básicos; 2018 [cited 2018 Mar 27]; [about 3 p.]. Available at: https://infosida.nih.gov/ understanding-hiv-aids/. Spanish.

3. Pan American Health Organization. Tratamiento de las enfermedades infecciosas 2017-2018. 7th ed [Internet]. Washington, D.C.: Pan American Health Organization; 2016 [cited 2018 Apr 1]. 316 p. Available at: https://iris.paho.org/bit stream/handle/10665.2/51590/9789275319161 spa.pdf?sequence=1\&isAllowed=y. Spanish.

4. Žhao Y, Wu Z, Mc Googan JM, Shi CX, Li A, Dou Z, et al. Immediate antiretroviral therapy decreases mortality among patients with high CD4 counts in China: a nationwide, retrospective cohort study. Clin Infect Dis [Internet]. 2018 Mar 1 [cited 2018 Apr 2];66(5):727-34. Available at: doi.org/10.1093/cid/cix878

5. UNAIDS [Internet]. Geneva: UNAIDS; c2021. Nuestra Acción. Datos. UNAIDS Data; 2018 Jul 26 [cited 2018 Aug 10]. Available at: https://www .unaids.org/es/topic/dataUNAIDS. Spanish.

6. UNAIDS; c2021. Centro de Prensa. Hoja informativa - Últimas estadísticas sobre el estado de la epidemia de SIDA; 2020 [cited 2020 Dec 23] Available at: www.unaids.org/es/resources/fact -sheet. Spanish.

7. U.S Department of Health and Human Services. Visión general de la infección por el VIH [Internet]. infoSIDA; 2018 [cited 2018 Mar 29]. Available at: https://infosida.nih.gov/understand ing-hiv-aids/. Spanish.

8. UNAIDS. Estrategias ONUSIDA para 2016-2021. Acción acelerada para acabar con el sida [Internet]. Geneva: UNAIDS; 2016 [cited 2018 Apr 1] 130 p. Available at: www.unaids.org/sites/default/ files/media_asset/UNAIDS-strategy-2016-2021 _es.pdf. Spanish.

9. INFOMED [Internet]. Havana: Ministry of Public Health (CU); c1999-2021. Legislación para el Sistema Nacional de Salud. Plan Estratégico Nacional para la Prevención y Control de las ITS, el VIH y las Hepatitis. 2019-2023 Resolución ministerial 56/2019; 2019 [cited 2020 Dec 23]. Available at: http://legislacion.sld.cu/index .php?P=FullRecord\&ID=362. Spanish

10. European Commission; World Health Organization, Pan American Health Organization. Experiencia cubana en la producción local de medicamentos, transferencia de tecnología y mejoramiento en el acceso a la salud [Internet]. Geneva: World Health Organization; 2015 [cited 2020 Dec 23]. Available at: https://www.who .int/phi/publications/sp-cuban_experience_local _prod_medstech_transfer/en/. Spanish.
11. Collazo Herrera M, Pérez Ávila J, Tápanes Pereza R, Pérez Correa D, Martínez Rodríguez A, Castro Peraza O, et al. Impacto económicosocial de la terapia antirretroviral de producción nacional para el VIH/sida en Cuba. Pharmaco Econom Spanish Res Art [Internet]. 2013 Mar 7 [cited 2020 Dec 25];6(1):1-12. Available at: https://doi.org/ 10.1007/BF03320847. Spanish.

12. World Health Organization [Internet]. Geneva: World Health Organization; c2021. Publicaciones. VIH. Tratamiento de la infección por el VIH. Transición hacia los nuevos antirretrovirales en los programas contra el VIH. Sinopsis política; 2017 Jul [cited 2020 Dec 23]. 8 p. Available at: www.who.int/hiv/pub/toolkits/transition-to-new -arv/es/. Spanish, English.

13. Martínez Rodríguez A, Duque Vizcaíno M, Castro Peraza O, Alfonso Orta I, Jiménez López G, Acosta Reynaldo ED. Notificaciones espontáneas de sospechas de reacciones adversas a los medicamentos. Instituto "Pedro Kouri". Rev Cubana Farm [Internet]. 2016 Jan-Mar [cited 2018 Apr 2];50(1):53-67. Available at: http:// scielo.sld.cu/scielo.php?script=sci_arttext\&pid =S0034-75152016000100006. Spanish.

14. HIVinfo.NIH.gov [Internet]. Washington, D.C.: U.S Department of Health and Human Services; c2021. EI VIH/SIDA. Hojas informativas. Medicamentos contra el VIH y sus efectos secundarios; 2018 [cited 2018 Mar 29]. Available at: https:// hivinfo.nih.gov/es/understanding-hiv/fact-sheets/ 
medicamentos-contra-el-vih-y-sus-efectos -secundarios. Spanish.

15. Santos Corraliza E, Fuertes Martín A. Efectos adversos de los fármacos antirretrovirales: Fisiopatología, manifestaciones clínicas y tratamiento. An Med Interna (Madrid) [Internet]. 2006 Jul [cited 2018 Mar 29];23(7):33844. Available at: http://scielo.isciii.es/scielo .php? script=sci_arttext\&pid=S0212-7199 $2006000700010 \&$ Ing=es. Spanish.

16. Pharmacovigilance National Coordination Unit (CU). Balance Anual 2014 [Internet]. Havana: Ministry of Public Health (CU); 2014 Jan [cited 2018 Apr 5]. 3 p. Available at: https://files.sld .cu/cdfc/files/2015/01/farmacovigilancia-cuba -ano-2014.pdf. Spanish.

17. Morales Pérez M. Reacciones adversas a los antivirales. Sistema Cubano de Farmacovigilancia, 2003-2013 [Internet]. Havana: Convención de Salud para Todos 2015; 2015 [cited 2018 Apr 8]. 9 p. Available at: http://www.con vencionsalud2015.sld.cu/index.php/conven cionsalud/2015/paper/view/819/758. Spanish.

18. Pérez-Rodríguez I, Pérez-Salgado D, CompeánDardón MS, Staines-Orozco MG, Ortíz-Hernández L. Side effects of antiretroviral treatment and adherence in patients with HIV from two public institutions at Mexico City. Med Int Méx [Internet]. 2016 Jul [cited 2020 Dec 22];32(4):396-406. Available at: https://www.mediagraphic.com/ pdfs/medintmex/mim-2016164d.pdf. Spanish.

19. Frometa Báez M, Alfonso Orta I, Martínez Rodríguez A. Reacciones adversas a los antirretrovirales en pacientes VIH/SIDA. Instituto Pedro Kourí, 2015. Rev Cub Tecnol Salud [Internet]. 2016 [cited 2018 Apr 9];8(1):12-9. Available at: http://www.medigraphic.com/pdfs/revcubtecsal/ cts-2017/cts171c.pdf. Spanish.

20. Martínez Rodríguez A, Duque Vizcaíno M, Castro Peraza O, Alfonso Orta I, Jiménez López G, Acosta Reynaldo ED. Notificaciones espontáneas de sospechas de reacciones adversas a los medicamentos. Instituto "Pedro Kourí". Rev Cubana Farm [Internet]. 2016 [cited 2018 Apr 8];50(1):53-67. Available at: https:// www.medigraphic.com/cgi-bin/new/resumen .cgi?IDARTICULO=72063. Spanish.

21. Mendo Alcolea N, Mesa Pérez EJ, Neyra Barrios R, Berenguer Gournaluses L, Nieto Muñiz G. Reacciones adversas a medicamentos antirretrovirales en pacientes con virus de inmunodefiencia humana. MEDISAN [Internet]. 2018 [cited 2020 Dec 22];22(8):674-82. Available at: http:// scielo.sld.cu/scielo.php?script=sci_abstract \&pid=S1029-30192018000800674\&lng=pt\&nrm =iso. Spanish.

22. Jiménez López G, Alfonso Orta I. Normas y procedimientos de trabajo del Sistema Cubano de Farmacovigilancia [Internet]. Havana: Ministry of Public Health (CU), National Pharmacovigilance Coordination Unit (CU); 2011 Dec [cited 2018 Jan 7]. 98 p. Available at: https://www.cecmed .cu/file/2623/download?token=yRWtIJD6. Spanish.

23. World Health Organization [Internet]. Geneva: World Health Organization; c2021. All of IRIS. This Collection. International monitoring of adverse reaction to drugs. Adverse reaction terminology. 31 December 1992. The Uppsala Monitoring Centre Uppsala, Sweden [updated 2017
Sep 26; cited 2018 Dec 23]. Available at: https:// apps.who.int/iris/handle/10665/61056

24. Shumock GT, Thorton JP. Focusing on preventability of adverse drug reactions. Hosp Pharm. 1992 Jun;27(6):538.

25. Otero López MJ, Alonso Hernández P, Maderuelo Fernández JA, Ceruelo Bermejo J, DomínguezGil Hurlé A, Sánchez Rodríguez A. Prevalencia y factores asociados a los acontecimientos adversos prevenibles por medicamentos que causan el ingreso hospitalario. Farm Hosp. 2006 MayJun;30(3):161-70. Spanish.

26. National Health Statistics and Medical Records Division (CU). Anuario Estadístico de Salud 2016 [Internet]. Havana: Ministry of Public Health (CU); 2017 Apr 13 [cited 2018 May 22]. Available at: http://www.sld.cu/noticia/2017/04/13/publicado -el-anuario-estadistico-de-salud-2016. Spanish.

27. Zacarías Leguizamón J. Reacciones adversas más frecuentes de los fármacos antirretrovirales. Rev Virtual Soc Paraguaya Med Intern [Internet]. 2014 Aug 18 [cited 2016 Oct 8];1(2):13-27. Available at: http://dx.doi.org/10.18004/rvspmi/ 2312-3893/2014.01(02)13-027. Spanish.

28. Morales Pérez M, García Milian AJ. Reacciones adversas evitables graves por antivirales. Sistema Cubano de Farmacovigilancia, 2008-2017. Horiz Sanitario [Internet]. 2019 Jan-Apr [cited 2019 Jan 8];18(1):57-66. Available at: https:// doi:10.19136/hs.a18n1.2402. Spanish.

29. Cruz Rojas PJ. Potenciales efectos adversos producidos tras la instauración de la terapia antirretroviral en pacientes ambulatorios infectados con VIH-SIDA [thesis] [Internet]. [Quito]: Universidad Técnica de Machala (EC); 2017 [cited 2018 Apr 6]. Available at: http://repositorio.ut machala.edu.ec/handle/48000/10070. Spanish.

30. Diariomedico.com [Internet]. Madrid: Grupo Recoletos; c2021. Microbiología y Enfermedades Infecciosas. 10 años de VIH. La terapia del VIH evoluciona para adaptarse a cada paciente; 2017 Nov 21 [cited 2020 Dec 23]. Available at: https://www.diariomedico.com $/ \mathrm{me}$ dicina/enfermedades-infecciosas/la-terapia-del -vih-evoluciona-para-adaptarse-a-cada-pacien te.html. Spanish.

31. Marinho TM, Rodrigues PM, Caixas $U$, Antunes AMM, Branco T, Harjivan SG, et al. Differences in nevirapine biotransformation as a factor for its sex-dependent dimorphic profile of adverse drug reactions. J Antimicrob Chemother [Internet] 2014 Feb [cited 2018 May 21];69(2):476-82 Available at: https://doi.org/10.1093/jac/dkt359

32. Bastida C, Grau A, Márquez M, Tuset M, de Lazzari E, Martínez E, et al. Polifarmacia e interacciones farmacológicas potenciales en una población envejecida con infección por el VIH. Farm Hosp [Internet]. 2017 Sep 1 [cited 2018 Apr 8];41(5):618-24. Available at: https://dx.doi .org/10.7399/fh.10778. Spanish.

33. Rodríguez Roque GJ. Respuesta clínica e inmunovirológica a la terapia antirretroviral combinada al año en una cohorte de pacientes con diagnóstico de VIH atendidos en el hospital Dr. Roberto Calderón Gutiérrez en el periodo enero-diciembre 2015 [thesis] [Internet]. [Managua]: Universidad Nacional Autónoma de Nicaragua; 2017 [cited $2018 \mathrm{Apr} 6$ ]. 63 p. Available at: http://repositorio.unan.edu.ni/4304/1/96901 .pdf. Spanish.
34. Serrano López de la Hazas JI. Interacciones farmacológicas de los nuevos antirretrovirales. Farm Hosp [Internet]. 2011 Jan-Feb [cited 2018 May 21];35(1):36-43. Available at: https:// www.sciencedirect.com/science/article/abs/pii/ S1130634310002308. Spanish, English.

35. Puertas MC, Ploumidis G, Ploumidis M, Fumero $E$, Clotet B, Walwort CM, et al. Pan-resistant HIV-1 emergence in the era of integrase strand-transfer inhibitors: a case report. Lancet Microbe [Internet]. 2020 Jul 1 [cited 2020 Dec 23];1(3):e130-5. Available at: https://www .thelancet.com/journals/lanmic/article/PIIS2666 -5247(20)30006-9/fulltext

36. Margot NA, Wong P, Kulkarni R, White K, Porter $\mathrm{D}$, Abram ME, et al. Commonly transmitted HIV-1 drug resistance mutations in reverse-tran scriptase and protease in antiretroviral treatment-naive patients and response to regimens containing Tenofovir Disoproxil Fumarate or Tenofovir Alafenamide. J Infect Dis [Internet] 2017 [cited 2018 May 20];215(6):920-7. Available at: https://doi.org/10.1093/infdis/jix015

37. Morales Pérez M, García Milian AJ. Papel de la superfamilia $A B C$ en la resistencia farmacológica. Horiz Sanitario [Internet]. 2017 [cited 2020 Dec 27];16(2):93-101. Available at: https:// revistas.ujat.mx/index.php/horizonte/article/ view/1469. Spanish.

38. World Health Organization [Internet]. Geneva: World Health Organization; c2021. Publications. HIV drug resistance report 2019; [updated 2019 Jul; cited 2020 Dec 23]. 68 p. Available at: http://www.who.int/hiv/pub/drugresistance/hivdr -report-2019/en

39. Gupta RK, Gregson J, Parkin N, Haile-Salassie $\mathrm{H}$, Tanuri A, Andrade Forero A, et al. HIV-1 drug resistance before initiation or re-initiation of first-line antiretroviral therapy in low-income and middle-income countries: a systematic review and meta-regression analysis. Lancet Infect Dis [Internet]. 2018 [cited 2020 Dec 23];18(2):139. Available at: https://dx.do .org/10.1016/S1473-3099(17)30702-8

40. Hamers RL, Rinke de Wit TF, Holmes CB. HIV drug resistance in low-income and middle-income countries. Lancet HIV [Internet]. 2018 [Cited 2020 Dec 23];5(10):e588-e596. Available at: https:// dx.doi.org/10.1016/S2352-3018(18)30173-5

41. Hamers RL, Inzaule S. Pan-resistant HIV-1: what's next? Lancet Microbe [Internet]. $2020 \mathrm{Jul}$ 1 [cited 2020 Dec 23];1(3):e97-e8. Available at: https://doi.org/10.1016/S2666-5247(20)30058-6. Spanish.

\section{THE AUTHOR}

Mayasil Morales-Pérez (mayasilmp@infomed sld.cu), physician with dual specialties in family medicine and pharmacology, with a master's degree in pharmacoepidemiology. Researcher, Medical University of Havana, Havana, Cuba

Submitted: June 15, 2020

Approved for publication: March 31, 2021 Disclosures: None 